J. Biosci., Vol. 20, Number 4, September 1995, pp 499-513. C Printed in India.

\title{
Heat shock response in mulberry silkworm races with different thermotolerances
}

\author{
OMANA JOY and KARUMATHIL P GOPINATHAN* \\ Department of Microbiology and Cell Biology and Centre for Genetic Engineering, Indian \\ Institute of Science, Bangalore 560 012, India
}

MS received 20 August 1994; revised 23 May 1995

\begin{abstract}
The thermal sensitivity and heat shock response of the different races of the mulberry silkworm Bombyx mori have been analysed. The multivoltine race, strains $C$. Nichi and Pure Mysore showed better survival rates than the bivoltine race, strain NB4D2 exposed to $41^{\circ} \mathrm{C}$ and above. In general, the fifth instar larvae and the pupae exhibited maximum tolerance compared to the early larval instars, adult moths or the eggs. Exposure up to $39^{\circ} \mathrm{C}$ for 1 or $2 \mathrm{~h}$ was tolerated equally whereas temperatures above $43^{\circ} \mathrm{C}$ proved to be lethal for all. Treatment of larvae at $41^{\circ} \mathrm{C}$ for $1 \mathrm{~h}$ resulted in a variety of physiological alterations including increased heart beat rates, differential haemocyte counts, enlargement of granulocytes and the presence of additional protein species in the tissues and haemolymph. The appearance of a $93 \mathrm{kDa}$ protein in the haemolymph, fat bodies and cuticle, following the heat shocking of larvae in vivo was a characteristic feature in all the three strains examined although the kinetics of their appearance itself was different. In haemolymph, the protein appeared immediately in response to heat shock in C. Nichi reaching the maximal levels in $2-4 \mathrm{~h}$ whereas its presence was noticeable only after $2-4 \mathrm{~h}$ recovery time in Pure Mysore and bivoltine races. The fat body from both C. Nichi and NB4D2 showed the presence of $93 \mathrm{kDa}, 89 \mathrm{kDa}$ and $70 \mathrm{kDa}$ proteins on heat shock. The haemocytes, on the other hand, expressed only a $70 \mathrm{kDa}$ protein consequent to heat shock. The $93 \mathrm{kDa}$ protein in the haemolymph, therefore could have arisen from some other tissue, possibly the fat body. The $93 \mathrm{kDa}$ protein was detected after heat shock in pupae and adult moths as well, although the presence of an additional $(56 \mathrm{kDa})$ protein was also apparent in the adults. The presence of $46 \mathrm{kDa}$ and $28 \mathrm{kDa}$ bands in addition to the $93 \mathrm{kDa}$ band in the cuticular proteins immediately following heat shock was clearly discernible. The $70 \mathrm{kDa}$ band did not show much changes in the cuticular proteins on heat shock. In contrast to the changes in protein profiles seen in tissues and haemolymph following heat shock in vivo, the heat treatment of isolated fat body or haemolymph in vitro resulted in protein degradation.
\end{abstract}

Keywords. Bombyx mori; bivoltine silkworms; heat shock proteins; multivoltine silkworms; thermotolerance.

\section{Introduction}

Heat shock response is a universal physiological phenomenon exhibited by both prokaryotes and eukaryotes (Glover 1982; Ciechanover et al 1984; Chirico et al 1988; Laminet et al 1990; Hightower 1991; Feige and Mollenhauer 1992). It is normally manifested by the appearance of a set of new proteins or an increase in the quantity of certain specific, preexisting proteins in response to exposure of an organism or a cell to thermal- and other forms of stresses. The heat shock proteins

\footnotetext{
* Corresponding author.
} 
(HSP) are presumed to ensure survival under stressful conditions by involvement in damage protection or damage repair due to their action as molecular chaperons (Hightower 1991; Morimoto 1993). Generally, the heat shock response depends on the magnitude of temperature elevation and duration of exposure, and is relative to the environmental temperature at which the organism normally survives (Nakayama et al 1989; Nath and Lakhotia 1989). Cells which have been preexposed to thermal stress acquire a transient resistance against the killing effect of a subsequent thermal stress and such a thermotolerance is caused by an enhanced resistance of proteins against thermal denaturation and aggregation (Kampinga 1993). The HSPs are also proposed to protect cells depleted in ATP from rapid necrotic death by inhibiting the aggregation of cytoskeletal proteins (Kabakov and Gabai 1994).

The heat shock response of organisms habitating tropical climate is likely to differ from those from temparate climate. This aspect has direct relevance in such commercially important areas as the field rearing of mulberry silkworms for silk production. The native Indian, multivoltine races of Bombyx mori (e.g., Pure Mysore, C. Nicht, Nistari strains) exhibit much more tolerance to high temperatures, often the field temperatures touching $40^{\circ} \mathrm{C}$ or more in summer, as against the exotic bivoltine races (e.g., NB4D2, NB18 strains) of temperate origin (Krishnaswamy et al 1977; Pershad et al 1986). The latter strains are better yielders of silk fibre in terms of quality and quantity but less popular with the farmers due to their higher susceptibility to environmental fluctuations. Although temperature and humidity have been known to play important role in silk production, not much information is available on the effect of temperature on silkworm physiology. Most of the heat shock studies have been carried out on cell- and tissue cultures or organisms from temperate climate (Ashburner 1970; Lindquist 1980, 1986; Carvalho and Rebello 1987; Sorger 1991). Here we have made a comparative analysis of the effect of heat shock on the tropical and exotic races of silkworm, B. mori, at different life stages.

\section{Materials and methods}

B. mori larvae (bivoltine race, strain NB4D2 and multivoltine race, strains $C$. Nichi and Pure Mysore) were reared in the laboratory on mulberry leaves, at $24-26^{\circ} \mathrm{C}$ and $60-85 \%$ relative humidity. The silkworm eggs, larvae, pupae and the adults were exposed to temperatures ranging from $37^{\circ} \mathrm{C}$ to $47^{\circ} \mathrm{C}$ for specified time. The heat treatment was always coupled to a relative humidity of $90 \%$. For every heat shock experiment, at least 20 larvae, 10 pupae or adults, or 100 eggs were used at any time, and each experiment was repeated at least 3 times. After the heat shock, the samples were returned to the rearing temperature and allowed to recover. Survival rate was assessed in the case of eggs by hatchability, larvae by their ability to enter succeeding instar or spin healthy cocoons, pupae by adult emergence, and adult by successful copulation and egg laying.

The effect of exposure to elevated temperature on physiological parameters was analysed. The heart beat rate was counted by examining the dorsal blood vessel of larvae, mounted on plasticin. The protein profiles of the haemolymph, fat body, silk glands and cuticle of the larvae, as well as the total proteins from the pupae and adult moths were analysed by sodium dodecyl sulphate-polyacrylamide gel electrophoresis (SDS-PAGE) (Laemmli 1970). 
Haemolymph from a cut proleg of the larvae was collected in a precooled graduated centrifuge tube containing a few crystals of phenyl thiourea (Gupta 1979). The haemolymph was centrifuged at $2000 \mathrm{~g}$ for $5 \mathrm{~min}$ at $4{ }^{\circ} \mathrm{C}$, and the supernatant was analysed for protein contents. For the isolation of haemocytes, the haemolymph from 20 larvae was pooled and centrifuged at $1000 \mathrm{~g}$ for $1 \mathrm{~min}$ at $4^{\circ} \mathrm{C}$ to remove the tissue debris, and the supernatant was centrifuged again at $5000 \mathrm{~g}$ for $10 \mathrm{~min}$ at $4{ }^{\circ} \mathrm{C}$. The sedimented haemocytes were examined under the microscope and lysed using the homogenization buffer (200 mM Tris-Cl, $\mathrm{pH} \mathrm{7.5;5} \mathrm{mM} \mathrm{MgCl}_{2}$; and 250 $\mathrm{mM} \mathrm{NaCl}$ ). For analysis of proteins, the fat body, silk gland and the cuticle were dissected from the heat shocked- or control larvae, and washed in Ringer (Irvine 1969). The tissues ( $1 \mathrm{~g} / \mathrm{ml}$ of Ringer) were homogenized using a teflon glass homogenizer. NP40 $(0.5 \% \mathrm{v} / \mathrm{v})$ was also included in the buffer while homogenizing the cuticle (Kiely and Riddiford 1985). The homogenates were centrifuged at 5000 $g$ for $10 \mathrm{~min}$ at $4^{\circ} \mathrm{C}$, and the supernatant after removal of the floating lipid layer was used for protein analysis.

Protein content was quantitated by the dye binding method (Bradford 1976). For in vivo labelling, the larvae were heat shocked for $30 \mathrm{~min}$ at $41^{\circ} \mathrm{C}$ and injected with $60 \mu \mathrm{Ci}$ of $\left[{ }^{35} \mathrm{~S}\right] \mathrm{Met}$ (specific activity, $8000 \mathrm{Ci} / \mathrm{mM}$ ) per larvae. The heat shock was continued for an additional $30 \mathrm{~min}$. The larvae were sacrificed and the tissues processed for protein analysis. The $\left[{ }^{35} \mathrm{~S}\right] \mathrm{Met}$ labelled proteins after SDS-PAGE were subjected to fluorography (Bonner and Lasky 1974).

In vitro heat shock studies were carried out by exposing the isolated fat body, cuticle (both maintained in insect Ringer) and haemolymph from control larvae to $41^{\circ} \mathrm{C}$ for $\mathrm{lh}$.

\section{Results}

\subsection{Effect of high temperature exposure on the survival of the silkworms}

The silkworm $B$. mori when exposed to high temperatures ranging from $37^{\circ} \mathrm{C}$ to $47^{\circ} \mathrm{C}$, showed varying levels of heat tolerance at the different developmental stages viz., the egg, larva, pupa and adult. The later larval instars and the pupal stages tolerated higher temperatures for longer durations as compared to the eggs or adults (figure 1). The data represent the maximum time they could be exposed at any given temperature to give $100 \%$ survival. The multivoltine $C$. Nichi strain normally reared at $24-26^{\circ} \mathrm{C}$, showed complete tolerance for exposures up to $39^{\circ} \mathrm{C}$ for $2 \mathrm{~h}$. However, on exposure to temperatures of $41^{\circ} \mathrm{C}$ or above, the survival rates reduced drastically. Beyond $43^{\circ} \mathrm{C}$, even a $10-20$ min exposure proved lethal to all the developmental stages of the insect.

The multivoltine $C$. Nichi and Pure Mysore larvae were more resistant than the bivoltine $N B 4 D 2$, when they were exposed to different temperatures for varying times (figure 2). The differences begin to appear at elevated temperatures of $41-43^{\circ} \mathrm{C}$ although they were equally tolerant to exposure at $39^{\circ} \mathrm{C}$ up to $2 \mathrm{~h}$. Between the two multivoltine races examined here, C. Nichi appeared to be marginally more tolerant than the Pure Mysore strain. In the case of bivoltine even when the larvae survived up to the cocoon spinning stage in some instances, they appeared placid. The fifth instar larvae at 3 days showed more thermotolerance than the younger 


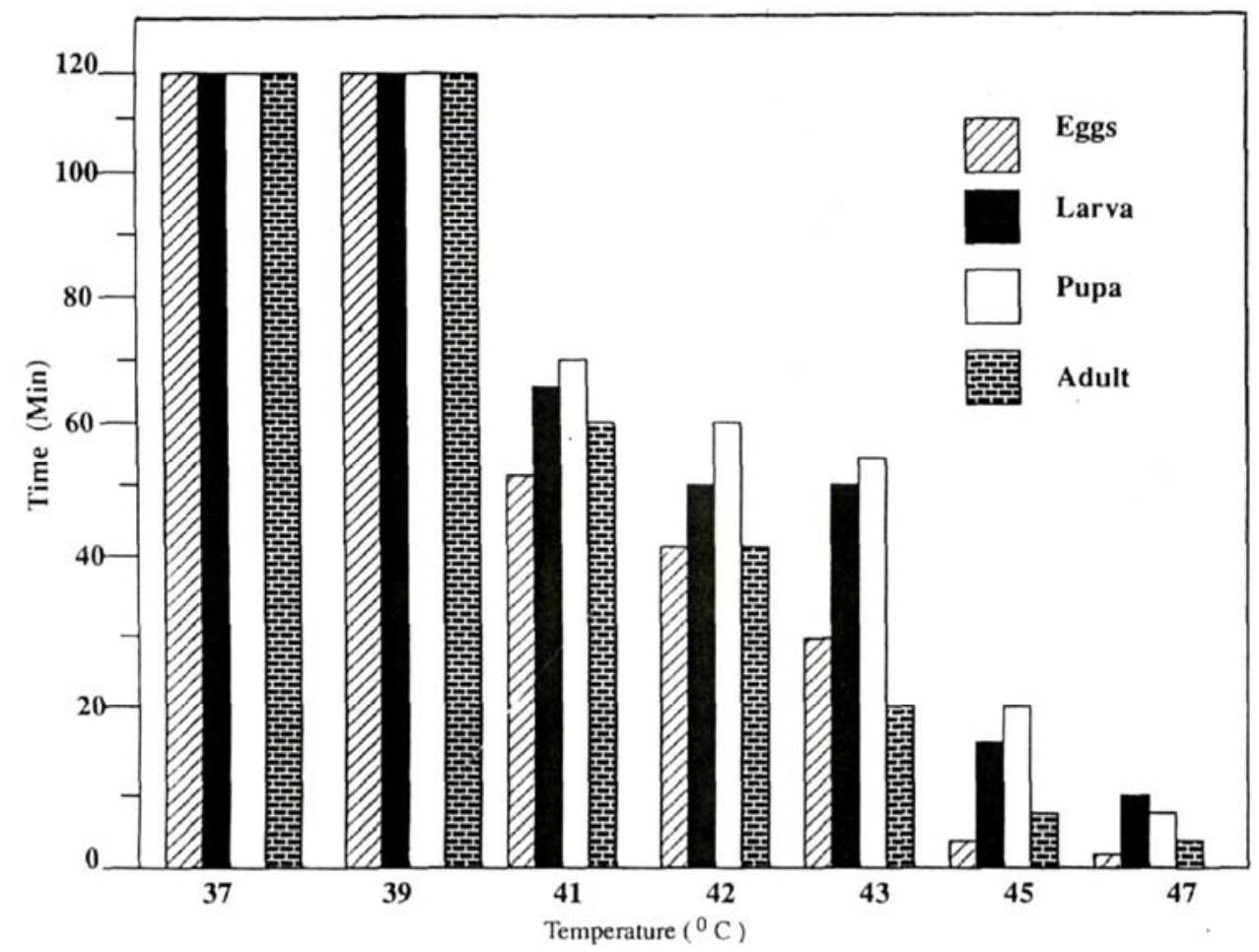

Figure 1 Effect of high temperature exposure on survival of silkworms.

The multivoltine race of B. mori, strain C. Nichi was reared in the laboratory between $24-26^{\circ} \mathrm{C}$. At different life stages of the organism, viz., eggs, larvae (fifth instar, day 3 ), pupae ( 2 days old and removed from the cocoon) and the adult moths were exposed to different temperatures from $37^{\circ} \mathrm{C}$ to $47^{\circ} \mathrm{C}$ for varying times (within 2 to 5 min increments at any given temperature to record $100 \%$ survival) as shown. The survival in the case of larva was judged by its capacity to enter the succeeding moult or to spin cocoon depending on the age of larvae. Hatchability was taken as the criterion for eggs. The survival of pupae was assessed by adult emergence and that of adult by successful copulation and egg laying.

larvae in the $41-43^{\circ} \mathrm{C}$ range in both multivoltine and bivoltine races when exposed for different times. Therefore, this age of larvae was chosen for all further heat shock studies.

\subsection{Physiological changes}

The heart beat (per min) of larvae ranged from $54 \pm 3$ in multivoltine to $58 \pm 3$ in bivoltine races. On exposure to high temperature, the heart beat rates increased in both races, the most pronounced one being the multivoltine Pure Mysore strain (table 1). Temperatures of $43^{\circ} \mathrm{C}$ or more, however, reduced the heart beat rate and the larva become placid. The haemolymph $\mathrm{pH}(6 \cdot 4$, in all three strains examined $)$ and volume $(1 \cdot 0 \pm 0 \cdot 1 \mathrm{ml}$ in $C$. Nichi and Pure Mysore, and $1 \cdot 6 \pm 0 \cdot 1 \mathrm{ml}$ in NB4D2) 


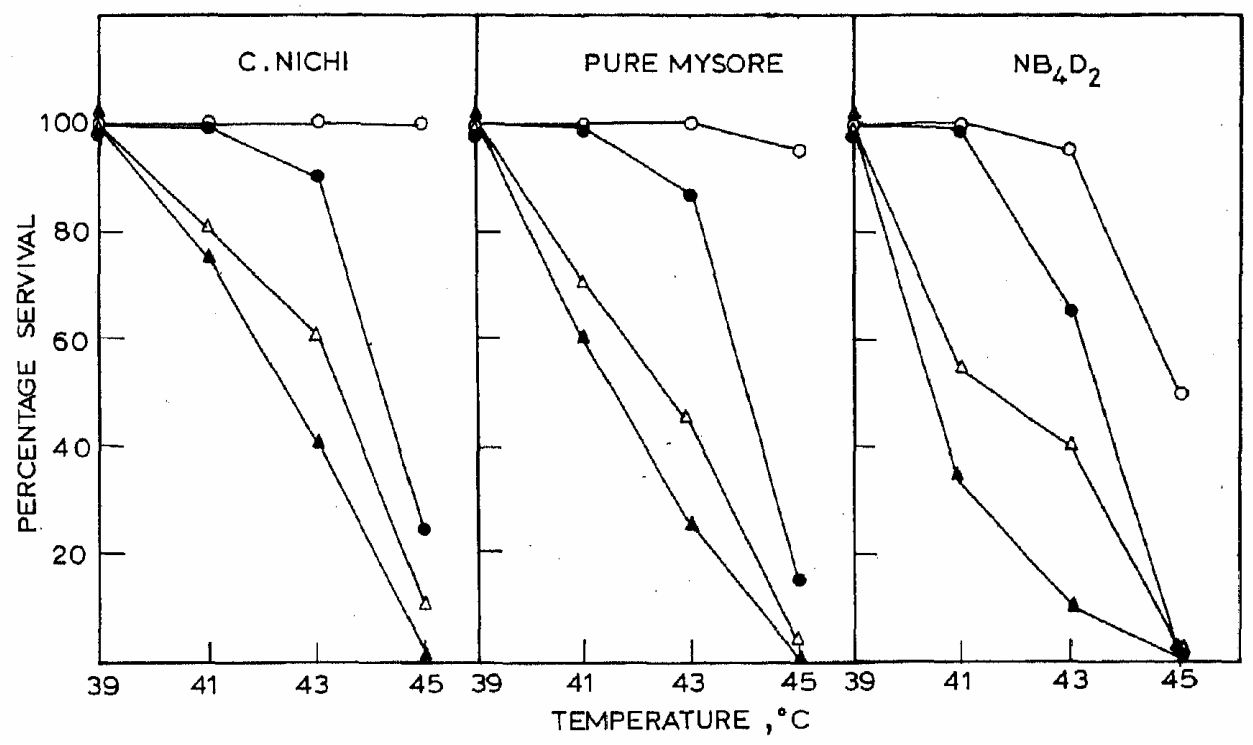

Figure 2. Thermal tolerance for varying exposure times.

Silkworm larvae (multivoltine, strains C. Nichi and Pure Mysore, and bivoltine, strain $N B 4 D 2$ ) normally reared at $24-26^{\circ} \mathrm{C}$ up to the fifth larval instar (3 days) when exposed to $39^{\circ}, 41^{\circ}, 43^{\circ}$ and $45^{\circ} \mathrm{C}$ for varying times $(30,60,90$ or $120 \mathrm{~min})$ as indicated. After heat shocking the larvae were brought back to normal rearing temperature. Survival of the larvae was assessed by their capacity to spin cocoons. Duration of exposure at different

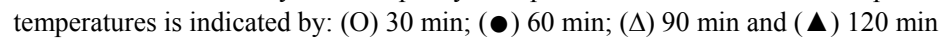

Table 1. Effect of temperature shock on physiological parameters.

\begin{tabular}{|c|c|c|c|c|c|c|c|c|}
\hline \multirow{3}{*}{$\begin{array}{l}\text { Silk } \\
\text { worm } \\
\text { strain }\end{array}$} & \multicolumn{8}{|c|}{ Population of haemocytes } \\
\hline & \multicolumn{2}{|c|}{$\begin{array}{c}\text { Granulocyte } \\
(\%)\end{array}$} & \multicolumn{2}{|c|}{$\begin{array}{c}\text { Plasmatocyte } \\
(\%)\end{array}$} & \multicolumn{2}{|c|}{$\begin{array}{c}\text { Oenocytoid }+ \\
\text { sperulocyte }(\%)\end{array}$} & \multicolumn{2}{|c|}{$\begin{array}{l}\text { Heart beat } \\
\text { (per min) }\end{array}$} \\
\hline & $26^{\circ} \mathrm{C}$ & $41^{\circ} \mathrm{C}$ & $26^{\circ} \mathrm{C}$ & $41^{\circ} \mathrm{C}$ & $26^{\circ} \mathrm{C}$ & $41^{\circ} \mathrm{C}$ & $26^{\circ} \mathrm{C}$ & $41^{\circ} \mathrm{C}$ \\
\hline C. Nichi & $46 \pm 4$ & $40 \pm 6$ & $47 \pm 6$ & $53 \pm 11$ & $7 \pm 1$ & $7 \pm 2$ & $54.1 \pm 3.6$ & $79 \cdot 6 \pm 7 \cdot 3$ \\
\hline Pure Mysore & $44 \pm 2$ & $30 \pm 9$ & $48 \pm 8$ & $53 \pm 11$ & $8 \pm 2$ & $8 \pm 1$ & $54.8 \pm 3 \cdot 3$ & $87 \cdot 7 \pm 5 \cdot 1$ \\
\hline$N B 4 D 2$ & $47 \pm 5$ & $43 \pm 11$ & $44 \pm 10$ & $48 \pm 14$ & $9 \pm 1$ & $9 \pm 1$ & $58.5 \pm 3.4$ & $82.6 \pm 4.4$ \\
\hline
\end{tabular}

The different strains of silkworm B. mori, reared at $24-26^{\circ} \mathrm{C}$ were exposed to $41{ }^{\circ} \mathrm{C}$ for $1 \mathrm{~h}$ and the physiological parameters were enumerated. The number of haemocytes per $\mathrm{mm}^{2}$ NB4D2, Pure Mysore and $C$. Nichi on an average was 1642, 1730 and 1875 respectively. The percentage of different populations of haemocytes was calculated on this basis.

did not show variations consequent to heat shock. The total protein contents in different tissues or haemolymph were also not affected by heat shock (data not shown).

The total haemocyte population did not show much variation in the heat shocked larvae. However, the differential count of plasmatocyte and granulocyte showed variations, the former decreasing by $8-12 \%$ and the latter showing a corresponding 
increase, in all three strains (table 1). The counts of spherulocyte + oenocytoids did not change. The haemocytes from control larvae always showed a characteristic feature of crowding when a droplet of the haemolymph was placed on a glass slide but this character was significantly reduced in haemolymph from heat shocked larvae. The haemocytes of bivoltine NB4D2 were generally larger than their counterparts from the multivoltine C. Nichi (figure 3). The size of granulocyte increased on heat shock in both races, but the enlargement was more prominent in the latter. In $C$. Nichi, on an average the granulocyte diameter increased from $3 \cdot 5 \pm 0 \cdot 8 \mu \mathrm{m}$ to $5 \cdot 1 \pm 0 \cdot 4 \mu \mathrm{m}$ whereas in $N B 4 D 2$, the increase was from $5 \cdot 1 \pm 0.6 \mu \mathrm{m}$ to $5 \cdot 5 \pm 0 \cdot 9 \mu \mathrm{M}$.

In pupae (removed from cocoon), exposure to high temperature increased the movement of the posterior part of the body. Beyond $43^{\circ} \mathrm{C}$, the adult emergence was reduced to $5 \%$. The adult moths showed enhanced wing fluttation on increase in environmental temperature and fecundity was reduced to $30 \%$ by $41^{\circ} \mathrm{C}$. The eggs kept above $41^{\circ} \mathrm{C}$ changed to a brick red colour and the hatchability was reduced to zero.

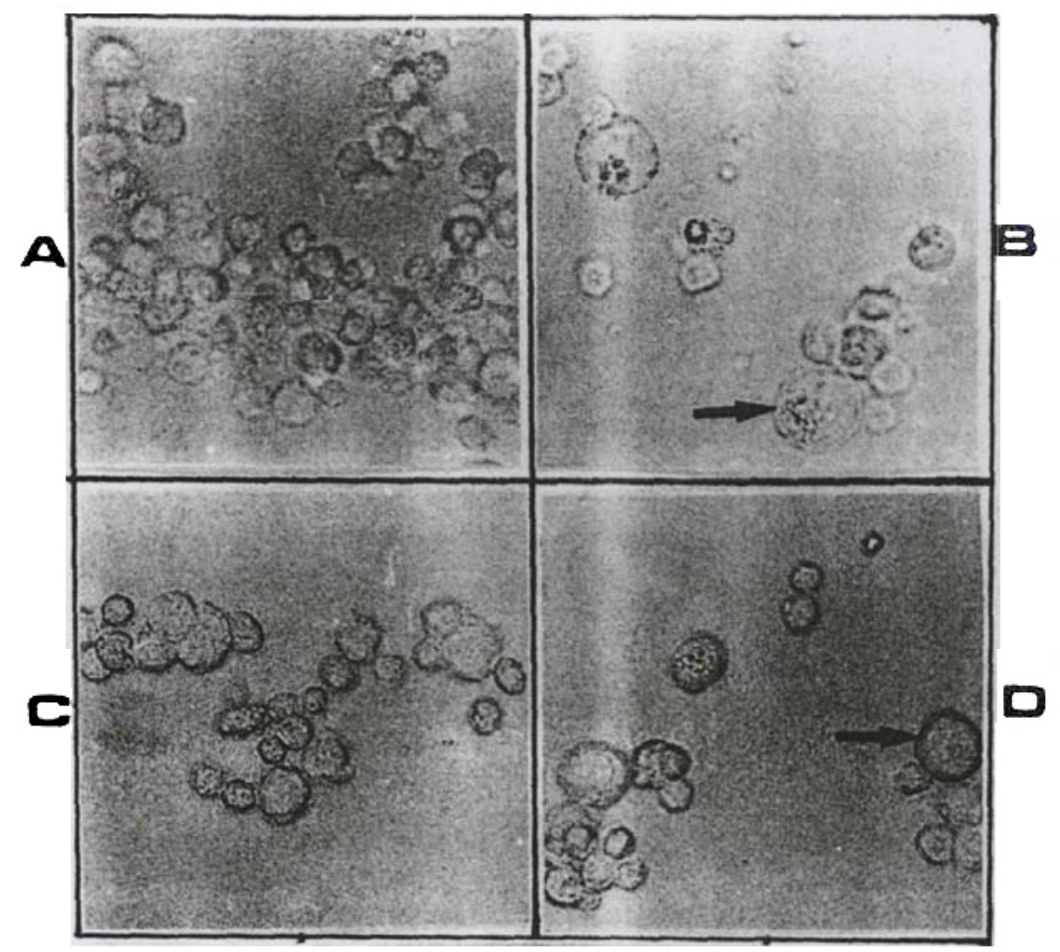

Figure 3. Haemocytes from control and heat shocked larvae.

The larvae (fifth instar, day 3) were subjected to a thermal shock of $41^{\circ} \mathrm{C}, 1 \mathrm{~h}$ and the haemolymph was collected immediately. The haemocytes were isolated by centrifugation at $5000 \mathrm{~g}$ and examined under phase contrast microscope (X 1600). The enlargement in granulocytes is clearly seen (indicated by arrow).

Haemocytes, from C. Nichi. (A, B) and NB4D2 (C, D), control and heat shocked. 


\subsection{Protein profiles from heat shocked larvae}

3.3a Haemolymph: The protein profiles of haemolymph from heat shocked larvae in comparison to the control (nonheat shocked) or those allowed to recover from the heat shock are presented in figure 4 (A-C). A total of 12-15 protein bands were present in C. Nichi, Pure Mysore as well as NB4D2 strains. The appearance of new $93 \mathrm{kDa}$ protein band consequent to exposure to high temperature was clearly discernible in all of them but their kinetics differed. In C. Nichi this protein band appeared immediately on exposure to $41^{\circ} \mathrm{C}$ and its level remained high during the 2-4 $\mathrm{h}$ recovery time at $26^{\circ} \mathrm{C}$ following the heat shock. In Pure Mysore and bivoltine $N B 4 D 2$ strains, the $93 \mathrm{kDa}$ protein band could be seen only after $2 \mathrm{~h}$ recovery from thermal shock. There were no noticeable changes in any of the other protein bands. Exposure of larvae to temperatures up to $39^{\circ} \mathrm{C}$ for $1 \mathrm{~h}$ did not result in any change in the haemolymph protein profiles compared to the controls.

The appearance of the $93 \mathrm{kDa}$ protein band in the haemolymph of C. Nichi was confirmed also by in vivo $\left[{ }^{35} \mathrm{~S}\right]$ Met labelling studies (figure $4 \mathrm{~A}$, lanes 5 and 6). In contrast to the in vivo result, when the haemolymph isolated from control larvae (reared at $26^{\circ} \mathrm{C}$ ) was exposed to $41^{\circ} \mathrm{C}$ for $1 \mathrm{~h}$ (in vitro heat shocking) the heat shock resulted in protein degradation.

Since the HSPs are known to be nonsecretory, the appearance of a new protein band $(93 \mathrm{kDa})$ in haemolymph was unexpected. In order to see whether this protein band had arisen from the haemocytes which populate the haemolymph, the protein pattern of the isolated haemocytes from such heat shocked larvae was examined. Only a few protein bands were seen in haemocytes but the appearance of a new $70 \mathrm{kDa}$ protein band was conspicous in C. Nichi haemocytes, $2 \mathrm{~h}$ post recovery from thermal shock (figure $4 \mathrm{D}$, lanes $1-3$ ). This protein band was clearly absent in NB4D2 haemocytes (figure 4D, lanes 4-6). However, the $93 \mathrm{kDa}$ protein band was not seen in either race.

3.3b Heat shock proteins from fat bodies: The protein profiles of fat bodies derived from control larvae and those exposed to $41^{\circ} \mathrm{C}$ for $1 \mathrm{~h}$, of multivoltine C. Nichi and bivoltine $N B 4 D 2$ races are presented in figure 5. As seen in the haemolymph, the most characteristic change was in the appearance of the $93 \mathrm{kDa}$ band in both C. Nichi (figure 5A), and NB4D2 (figure 5B) following heat shock. In addition, a $89 \mathrm{kDa}$ band was also observed. In C. Nichi, the $70 \mathrm{kDa}$ protein was detectable in the control larvae, which increased on heat shock and stayed at high levels during the entire recovery time (figure $5 \mathrm{~A}$ ). Although the $70 \mathrm{kDa}$ band was apparent also in the bivoltine $N B 4 D 2$, the changes in its level on heat treatment did not vary as conspicously as in $C$. Nichi. The fat body proteins from larvae heat shocked at $39^{\circ} \mathrm{C}$ also did not show any change in their profiles. Subjecting the isolated fat bodies from control larvae to heat shock for $1 \mathrm{~h}$ at $41^{\circ} \mathrm{C}$, again resulted in protein degradation as was observed in the case of haemolymph.

In vivo labelling with $\left[{ }^{35} \mathrm{~S}\right]$ Met during heat shock confirmed the 89 and $93 \mathrm{kDa}$ proteins in fat bodies of $C$. Nichi although no prominent change was apparent in the level of $70 \mathrm{kDa}$ protein (figure 5A, lanes 5 and 6).

3.3c Cuticules: The cuticle protein pattern from the C. Nichi strain is presented in figure 6 . The protein profiles were more complex due to the presence of larger 
number of protein species. Nevertheless, in C. Nichi, the presence of additional protein bands at $93 \mathrm{kDa}, 46 \mathrm{kDa}$ and $28 \mathrm{kDa}$ immediately on exposure to $41^{\circ} \mathrm{C}$ was distinct. The $70 \mathrm{kDa}$ protein band was clearly seen but did not show much change in the level on heat shock. The appearance of these protein bands in C. Nichi following heat shock was also confirmed from the in vivo $\left[{ }^{35} \mathrm{~S}\right]$ Met labelling studies (lanes 5 and 6). These changes were similar in cuticle proteins from the Pure Mysore and NB4D2 strains (data not shown).

3.3d Silk gland proteins: The silk gland proteins from the heat shocked larvae did not show any clear changes in the protein profiles. Fifth instar larvae start synthesizing large quantities of proteins from third day onwards and these proteins

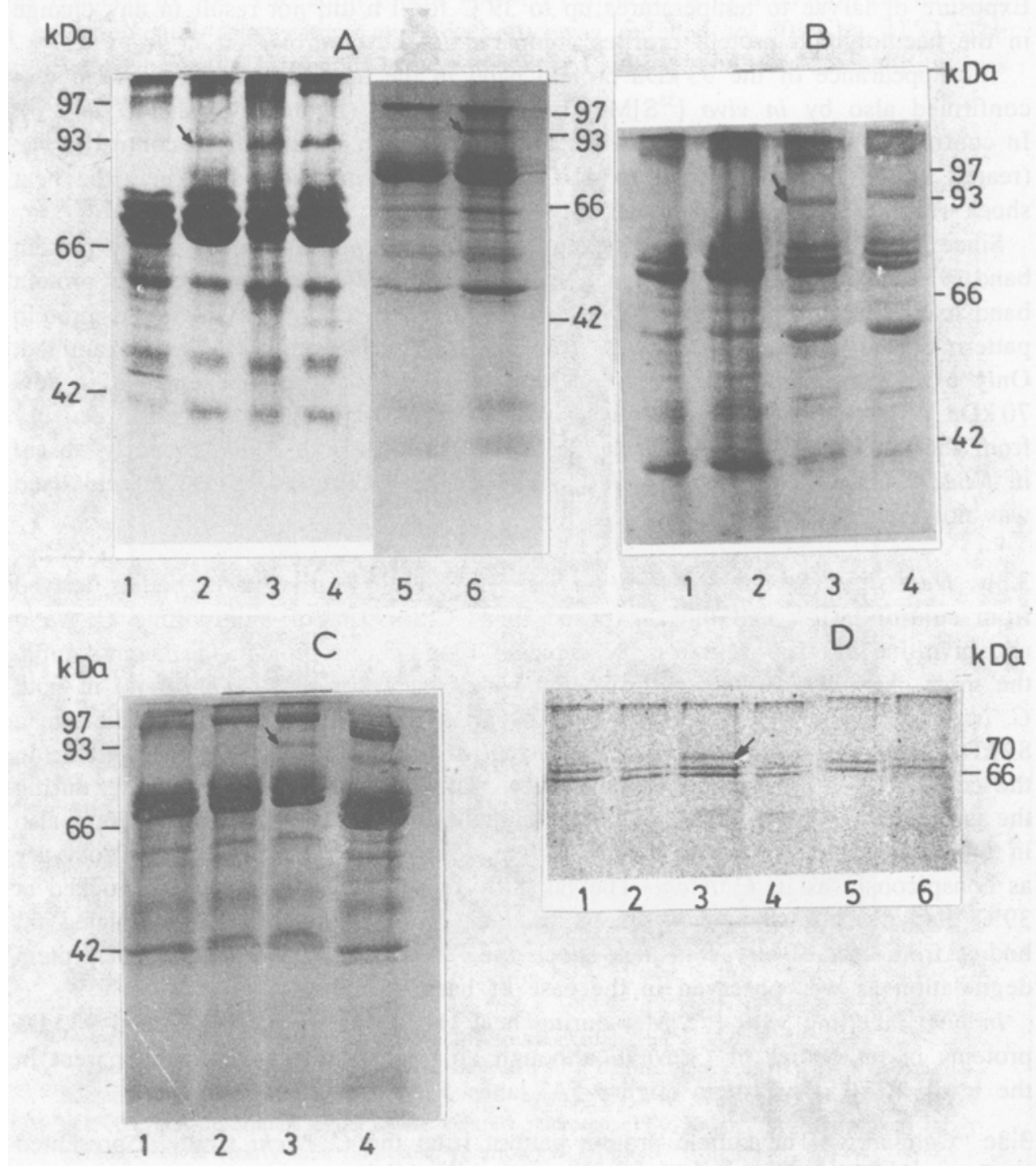


could have masked the HSPs. Alternatively, the absence of HSPs could be attributed to the silk glands not sensing the shock due to their location within the larvae, covered by haemolymph, fat body and cuticle. Due to such insulation, the heat stress may not even reach the silk glands, when the whole larvae is subjected to heat shock. The absence of HSPs in the silk gland could be a consequence of this and may not reflect the inability of the tissue to synthesize them. However, it should be noted that the haemocytes from C. Nichi though not NB4D2 showed the presence of HSP.

\subsection{Heat shock response in pupae and adult moths}

The protein profiles of pupae and the adult moths of $C$. Nichi when exposed to $41^{\circ} \mathrm{C}$ for $1 \mathrm{~h}$ are presented in figure $7(\mathrm{~A}, \mathrm{~B})$. At both stages, the $93 \mathrm{kDa}$ proteins appeared immediately on exposure to the high temperature. In adult moth, additionally the appearance of a $56 \mathrm{kDa}$ band was clear (figure 7B, lane 2 and 3). Further, some of the low molecular weight protein bands nearly disappeared after heat shock of the moth.

\section{Discussion}

Exposure of an organism or tissue to temperatures higher than the optimal growth temperature disturbs their normal function, ultimately resulting in death. An early consequence of heat shocking is the appearance of a set of highly conserved proteins, the HSPs, ubiquitous to all organisms examined so far. The HSPs are considered to confer protection against the adverse effect of heat shock (Hightower 1991). The susceptibility of economically important organisms such as the silkworms to environmental fluctuations of temperature, humidity etc., attain significance in their field-rearing for the commercial production of silk. The three strains of $B$. mori examined here, viz., $C$. Nichi and Pure Mysore of the multivoltine race, and $N B 4 D 2$ of the bivoltine race show different levels of tolerance for exposure to

Figure 4. Haemolymph proteins from heat shocked larvae.

Silkworm larvae (fifth instar, day 3) were exposed to $41^{\circ} \mathrm{C}$ for $1 \mathrm{~h}$. The haemolymph was collected and the proteins were separated on SDS-PAGE (12.5\%). The proteins were stained with Coomassie brilliant blue (lanes 1-4). For in vivo labelling of haemolymph proteins $\left[{ }^{35} \mathrm{~S}\right]$ Met $(60 \mu \mathrm{Ci}$ /animal) was injected to $C$. Nichi larvae (fifth instar, day 3 ) half way through the heat shock at $41^{\circ} \mathrm{C}$ for $1 \mathrm{~h}$. The haemolymph was collected immediately after heat shock and subjected to SDS-PAGE (12.5\%). For controls the silkworms maintained at $26^{\circ} \mathrm{C}$ were injected with $\left[{ }^{35} \mathrm{~S}\right] \mathrm{Met}(60 \mu \mathrm{Ci} /$ animal $)$ and the haemolymph was collected after $30 \mathrm{~min}$. The labelled proteins were detected by fluorography (lanes 5 and 6 in figure 5A).

(A) C. Nichi; (B) Pure Mysore; (C) NB4D2. Lanes: 1, control (no heat shock); 2, immediately after heat shock (no recovery time); 3 and 4 , recovery at $26^{\circ} \mathrm{C}$ after heat shock for 2 and 4 h respectively. Lanes 5 and 6 (figure 5A), labelled haemolymph proteins from control and in vivo heat shocked larvae. The $93 \mathrm{kDa}$ protein is indicated by arrow. (D) Haemocyte proteins. The haemocytes were isolated from control or heat shocked $\left(41^{\circ} \mathrm{C}\right.$, $1 \mathrm{~h})$ larvae (fifth instar, day 3 ), lysed and the proteins were analysed on SDS-PAGE (7.5\%). Lanes 1-3, haemocyte proteins from C. Nichi, control (no heat shock), immediately after heat shock and $2 \mathrm{~h}$ recovery after heat shock, respectively; Lanes $4-6$, haemocyte proteins from $N B 4 D 2$, control (no heat shock), immediately after heat shock and $2 \mathrm{~h}$ recovery after heat shock, respectively. The $70 \mathrm{kDa}$ protein band is indicated by arrow. 
temperatures higher than their normal growth temperature. C. Nichi was the most tolerant of the three while the exotic strain NB4D2 was most labile, as judged by their survival and capacity to spin cocoons after a $1 \mathrm{~h}$ heat shock. Temperatures above $43^{\circ} \mathrm{C}$ proved lethal for all of them. These observations are in general agreement with the commercial field rearing experience on the silkworms. The sensitivity to thermal exposure was also dependent on the life stages of the silkworm.

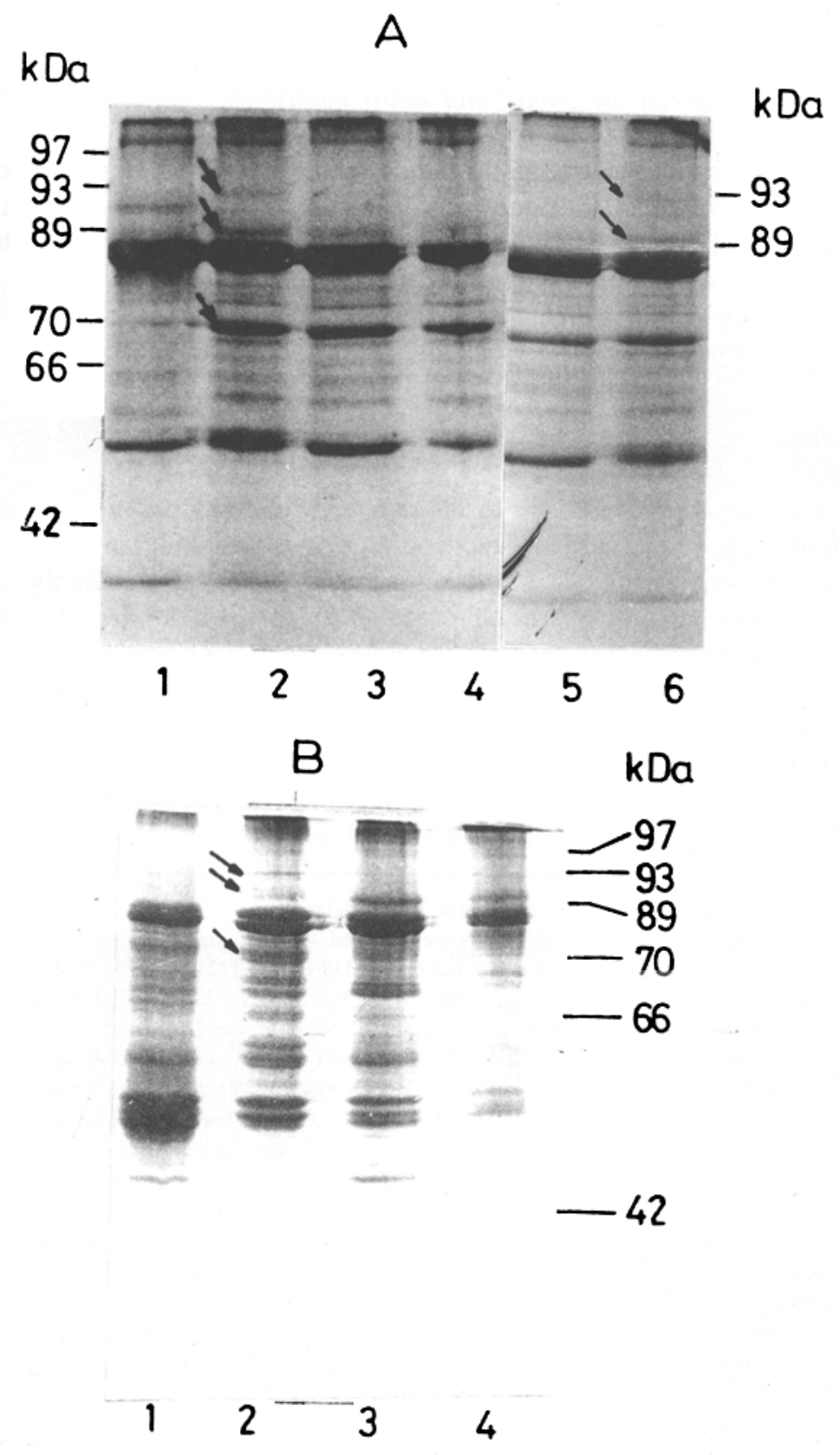


The fifth instar larvae and the pupae were more tolerant compared to the young larvae or the adult moths. The eggs were also very sensitive to temperature of $39^{\circ} \mathrm{C}$ and above, when the hatchability was reduced to zero.

Having assessed the differences in thermal tolerance of the various races, the effect of heat shocking the whole larvae on various physiological parameters, and the protein profiles of individual tissues or haemolymph of $B$. mori were analysed on a comparative basis. The approach used here is different from those attempted previously which were confined mostly to cells maintained in cultures. In haemolymph, fat bodies and cuticle, the appearance of a $93 \mathrm{kDa}$ protein consequent to heat shock was evident in the multivoltine and bivoltine races of silkworms analysed. However, there were differences in the time of their appearance, whether immediately on heat shock or after permitting them to go through a recovery period. The protein band made the appearance instantaneously after the heat shock in haemolymph of the more thermotolerant $C$. Nichi compared to the bivoltine NB4D2 where the protein appeared only after $2 \mathrm{~h}$, during recovery. The $70 \mathrm{kDa}$ protein was present constitutively in fat body and cuticle of both races. On heat shock, the levels of $70 \mathrm{kDa}$ protein showed substantial increase in the fat bodies, from C. Nichi.

The fat body is the reservoir and active synthetic tissue for most of the haemolymph and cuticular proteins (Shigematsu 1968; Wyatt and Pan 1978; Tojo et al 1981; Plantevin et al 1987). Only a small number of haemolymph proteins are synthesized by the haemocytes (Palli and Locke 1987; Shigematsu 1968; Dean et al 1985; Wyatt and Pan 1978). In the haemocytes from heat shocked C. Nichi, only the $70 \mathrm{kDa}$. was heat induced but the $93 \mathrm{kDa}$ protein was absent. There were no signs of haemocyte lysis or damage consequent to heat shocking. Since the $93 \mathrm{kDa}$ protein is seen after heat shock in the haemolymph, fat bodies and the cuticle, it is likely that the protein is synthesized in the latter tissues and found its way into the haemolymph. But so far, none of the HSPs have been shown to be secretory in nature. The haemolymph being an open circulation system most of the tissues including the fat bodies and silk glands lie bathed in haemolymph within the $B$. mori larvae. Consequently several proteins synthesized in the fat body find their way into the haemolymph (Shigematsu 1968; Dean et al 1985). Even nonsecretory proteins from the fat bodies may thus enter the haemolymph due to the immersion of the former in the haemolymph. This is a most likely reason for the presence of $93 \mathrm{kDa}$ protein in haemolymph.

The differences in the pattern of expression of HSPs in different tissues of silkworm, seen here are quite unusual. A complex regulatory pattern is seen in the

Figure 5. Effect of heat shock on fat body proteins.

Silkworm larvae (fifth instar, day 3) were subjected to heat shock at $41^{\circ} \mathrm{C}$ for $1 \mathrm{~h}$ and the fat bodies were dissected out. The total proteins were extracted in homogenization buffer and subjected to SDS-PAGE (12.5\%). For in vivo labelled proteins from fat bodies, C. Nichi larvae were injected with $\left[{ }^{35} \mathrm{~S}\right] \mathrm{Met}(60 \mu \mathrm{Ci} /$ animal $)$ midway during heat shock at $41^{\circ} \mathrm{C}$ for $1 \mathrm{~h}$, and the fat bodies were isolated immediately afterwards. For controls, the animals were injected with $\left[{ }^{35} \mathrm{~S}\right]$ Met and maintained at normal rearing temperature $\left(26^{\circ} \mathrm{C}\right)$ for $30 \mathrm{~min}$ before dissection. The positions of $93 \mathrm{kDa}, 89 \mathrm{kDa}$ and $70 \mathrm{kDa}$ proteins are indicated by arrows.

(A) C. Nichi; (B) NB4D2. Lanes: 1, control larvae; 2, immediately after heat shock; 3 and 4 , recovery at $26^{\circ} \mathrm{C}$ for 2 and $4 \mathrm{~h}$ respectively after heat shock. Lanes 5 and 6 (in A), labelled proteins from fat bodies of control and in vivo heat shocked larvae. 


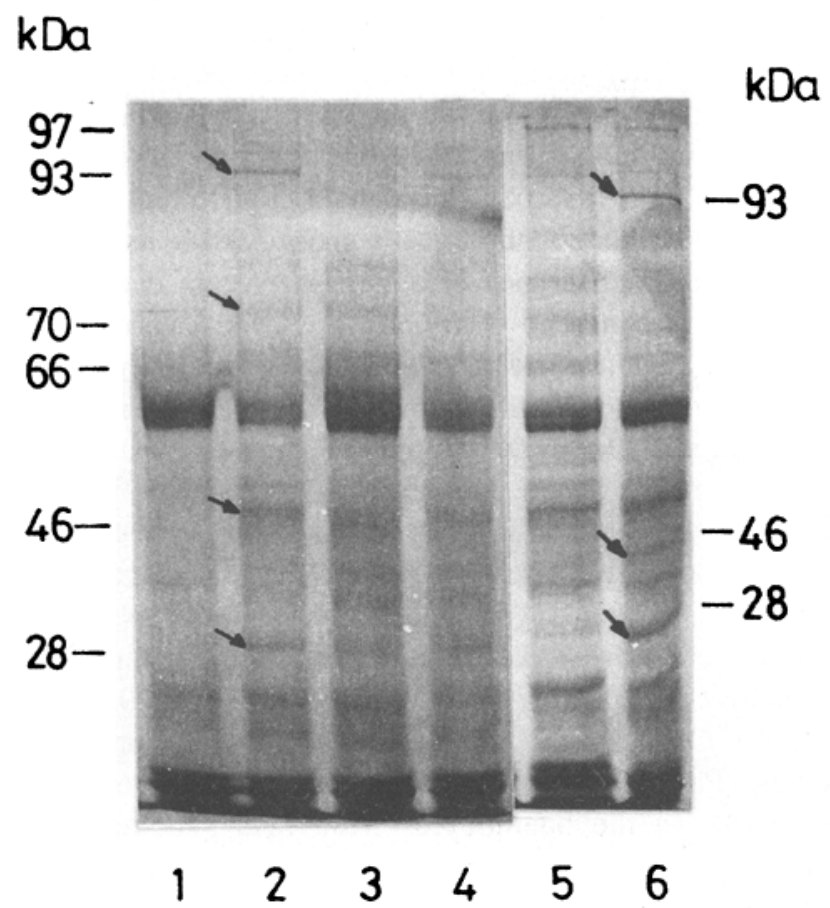

Figure 6. Cuticular proteins.

B. mori larvae (fifth instar, day 3), C. Nichi strain, were subjected to heat shock at $41^{\circ} \mathrm{C}$ for $1 \mathrm{~h}$ and the cuticles were separated out after removal of the internal tissues and organs. The cuticular proteins were extracted by homogenization and separated by SDS-PAGE $(12 \cdot 5 \%)$. Coomassie blue staining (lanes $1-4)$. For in vivo labelling of cuticular proteins, the experimental details were as under figure 5. The in vivo labelled cuticular proteins from C. Nichi separated on SDS-PAGE (12.5\%) were subjected to fluorography.

Lanes: 1, control (no heat shock); 2, immediately after heat shock; 3 and 4, recovery for 2 and $4 \mathrm{~h}$ at $26^{\circ} \mathrm{C}$ following heat shock; 5 and $6,\left[{ }^{35} \mathrm{~S}\right]$ Met labelled cuticle proteins from control (no heat shock) and immediately after heat shock. The arrows indicate the $93 \mathrm{kDa}, 70 \mathrm{kDa}, 46 \mathrm{kDa}$ and $28 \mathrm{kDa}$ bands.

case of hsp gene expression in the flesh fly, Sarcophaga crassipalpis (Joplin and Denlinger 1990). Here the expression of the different HSPs in different tissues vary depending on the stage of development or even the temperature at which the exposure was given. Coulon-Bublex and Mathelin (1991) had reported the appearance of a $70 \mathrm{kDa}$ stress response protein after heat shock or acid treatment of the diapausing embryos of $B$. mori, which was also present during deep diapause.

HSPs provide protection to cells against the heat induced damage (Pelham 1986) and the synthesis of HSPs is related to heat resistance (Bosch et al 1988; Lohmann and Riddiford 1990). Thermotolerance is expressed as an attenuation of damage formation or as a better repair of protein damage, termed facilitated recovery (Kampinga 1993). The total concentration of HSPs (both constitutive and inducible) and their redistribution to specific subcellular sites are considered as more important factors in the acquisition of thermotolerance (Kampinga 1993). In this respect, the 
A

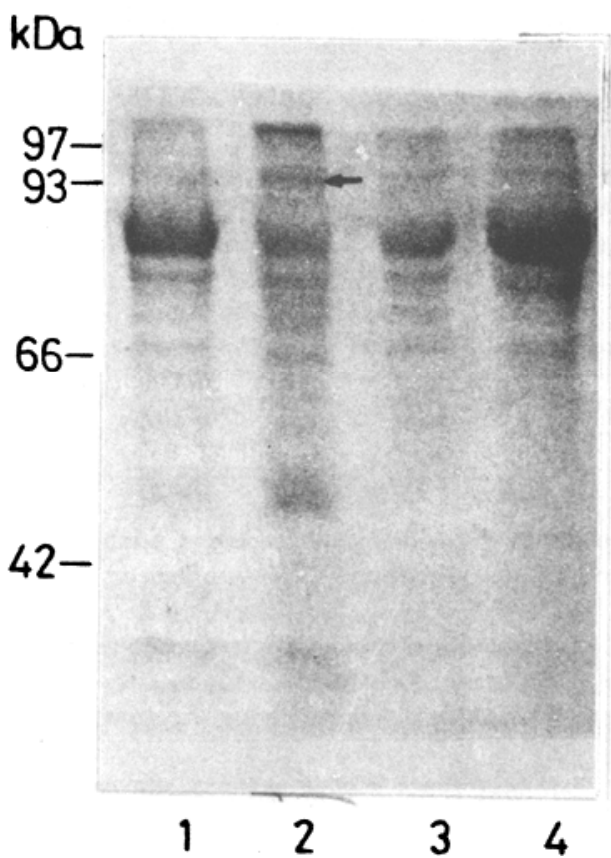

B

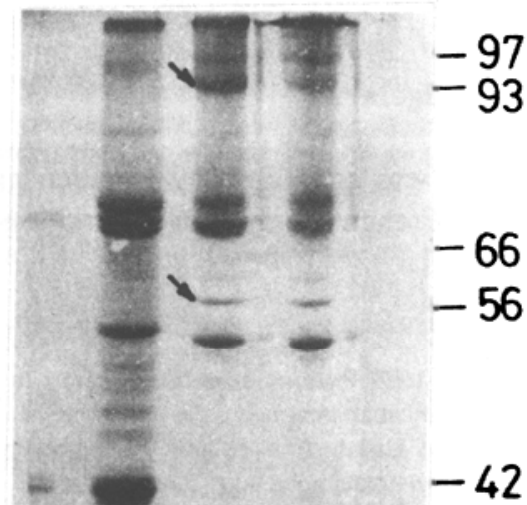

$-42$

Figure 7. Heat shock response in B. mori pupae or adult moths.

C. Nichi pupae (2 day old) removed from the cocoon (A), or the adult moth [on the day of emergence (B)] were subjected to heat shock at $41^{\circ} \mathrm{C}$ for $1 \mathrm{~h}$. The wings, legs and head were clipped off from the adults before protein extraction. The pupae and adults (an equal number of males and females mixed) were frozen in liquid nitrogen and the proteins were extracted by grinding thoroughly with homogenization buffer. The debris was removed by centrifugation at $8000 \mathrm{~g}$ and the supernatant was subjected to SDS-PAGE.

Lanes: 1, control; 2, immediately after heat shock; 3 , recovery at $26^{\circ} \mathrm{C}$ for $2 \mathrm{~h}$ following heat shock; 4 (in A), recovery for $4 \mathrm{~h}$ at $26^{\circ} \mathrm{C}$. The additional protein bands appearing after heat shock are marked by arrows.

presence of HSP in the haemolymph of $B$. mori can be considered as a desirable feature in conferring thermotolerance to the larvae.

Integuments consisting of the cuticle and the underlying epidermis are the external tissues which act as initial defense organ in most insects. Response of the integument to heat shock will therefore be an integral part of the survival of the silkworm. The appearance of $93 \mathrm{kDa}, 70 \mathrm{kDa}, 46 \mathrm{kDa}$ and $28 \mathrm{kDa}$ proteins was conspicous in all strains examined consequent to exposure to high temperature. The small molecular weight HSPs in cuticle of Manduca sexta have been speculated to provide an alteration in the relative water loss allowing evaporative cooling during heat shock (Lohmann and Riddiford 1992).

Our results here show that in vitro heat shocking of the isolated tissue or haemolymph at $41^{\circ} \mathrm{C}$ from control animals reared at $24-26^{\circ} \mathrm{C}$, generally resulted in protein degradation whereas subjecting the whole larvae to thermal shock for 
an identical time and temperature, resulted in the appearance of the additional protein bands. The synthesis of these proteins in vivo, in response to heat shock may therefore play important role in the thermal tolerance of the silkworms.

\section{Acknowledgements}

This work was supported by research grants from the Department of Biotechnology, and Indo French Centre for Promotion of Advanced Research, New Delhi.

\section{References}

Ashburner M 1970 Patterns of puffing activity in salivary gland chromosomes in Drosophila V. Response to environmental treatment; Chromosoma 31 356-376

Bonner W and Laskey R A 1974 A film detection method for tritium labelled proteins and nucleic acids in Polyacrylamide gels; Eur. J. Biochem. 46 83-88

Bosch T C G, Krylow S M, Rode H R and Steele R E 1988 Thermotolerance and synthesis of heat shock proteins: These responses are present in Hydra attenuata absent in Hydra oligaetis; Proc. Natl. Acad. Sci. USA 85 7927-7931

Bradford M M 1976 A rapid and sensitive method for the quantitation of microgram quantities of protein utilizing the principle of protein-dye binding; Anal. Biochem. 72 248-254

Carvalho M G C and Rebello M A 1987 Induction of heat shock proteins during the growth of Aedes albopietus cells; Eur. J. Biochem. 17 199-206

Chirico W J, Waters M J and Blobel G $198870 \mathrm{k}$ heat shock related proteins stimulate proteins translocation into microsomes; Nature (London) $332805-810$

Ciechanover A, Finley D and Varshaveky A 1984 Ubiquitin dependence of selective protein degradation demonstrated in the mammalian cell cycle mutant ts85; Cell 37 57-66

Coulon-Bublex M and Mathelin J 1991 Variations in the rate of synthesis of heat shock proteins HSP70, between laying and neurula, the diapausing embryo of the silkworm Bombyx mori; Sericologia 31 295-300

Dean R L, Locke M and Collins J V 1985 Structure of the fat body; in Comprehensive insect physiology biochemistry and pharmacology (eds) G A Kerkut and L I Gilbert (New York: Pergemon Press) pp $55-210$

Feige U and Mollenhauer J 1992 Heat shock proteins; Experientia 48 621-634

Glover C V C 1982 Heat shock from bacteria to man (eds) M Schlesinger, M Ashburner and A Tissieres (New York: Cold Spring Harbor Laboratory Press) pp 227-234

Gupta A P 1979 Insect hemocytes development forms, functions and techniques (Cambridge: Cambridge University Press)

Hightower L E 1991 Heat shock stress protein, chaperones and proteotoxicity; Cell 66 191-197

Irvine H B 1969 Sodium and potassium secretion by isolated insect malpigian tubules; Appl. J. Physiol. 217 1520-1527

Joplin K H and Denlinger D L 1990 Developmental and tissue specific control of the heat shock induced $70 \mathrm{kDa}$ related proteins in the flesh fly Sarcophaga crassipalpis; J. Insect Physiol. 36 239-249

Kabakov A E and Gabai V L 1994 Heat-shock proteins maintain the viability of ATP-deprived cells: What is the mechanism; Trends Cell Biol. 4 193-195

Kampinga H H 1993 Thermotolerance in mammalian cells: Protein denaturation and aggregation and stress proteins; J. Cell Sci. 104 11-17

Kiely M L and Riddiford L M 1985 Temporal programming of epidermal cell protein synthesis during the larval pupal transformation of Manduca sexta; Rous Archs. Dev. Biol. 194 325-335

Krishnaswamy S, Narasimhanna M N, Suryanaryan S K and Kumararaj S 1977 Manual on sericulture Vol. 2 Silkworm rearing (Mysore: Publ. Central Silk Board)

Laemmli U K 1970 Cleavage of structural proteins of the head of bacteriophage T4; Nature (London) 227 680-685

Laminet A A, Ziegelhofer T, Georgopoulos C and Pluckthun A 1990 The Escherichta coli heat shock proteins GroEL and GroES modulate the folding of the $\beta$-lactamase precursor; EMBO J. 9 2315-2319

Lindquist S 1980 Translational efficiency of heat induced messages in Drosophila melanogaster cells; 
J. Mol. Biol. 137 151-158

Lindquist S 1986 The heat shock response; Annu. Rev. Biocliem. 55 1151-1191

Lohmann C M F and Riddiford L M 1990 Heat sensitivity and protein synthesis during heat shock in the tobacco horn worms Manduca sexta; J. Comp. Physiol. B160 349-356

Lohmann C M F and Riddiford L M 1992 Synthesis and secretion of low molecular weight cuticular proteins during heat shock in the tobacco horn worm Manduca sexta; J. Exp. Zool. 262 374-382

Morimoto R I 1993 Cells in stress: Transcriptional activation of heat shock genes; Science 259 1409-1410 Nakayama Y, Spielman A and James A A 1989 Protein synthesis induced by heat in an Ixodex tick; Insect. Biochem. 19 731-736

Nath B B and Lakhotia S C 1989 Heat shock response in tropical chironomus: seasonal variation in response and the effect of developmental stage and tissue type on heat shock protein synthesis; Genome 32 676-686

Palli S R and Locke M 1987 The synthesis of hemolymph proteins by the larval epidermis of an insect Calpodes ethilus (Lepidoptera: heperiidae); Insect. Biochem. 17 711-722

Pelham H R B 1986 Speculations on the functions of the major heat shock and glucose-regulated proteins; Cell 38 959-961

Pershad G D, Datta R K, Vijayakumar H V, Bhargava S K and Jolly M S 1986 Performance of some multivoltine races of Bombyx mori L; Sericologia 26 295-301

Plantevin G, Bosquet G, Calvez B and Nardon C 1987 Relationship between juvenile hormone levels and synthesis of major haemolymph proteins in Bombyx mori larvae; Comp. Biochem. Physiol. B86 501-507

Shigematsu H 1968 Synthesis of blood protein by the fat body in the silkworm Bombyx mori L; Nature (London) 182 880-882

Sorger PK 1991 Heat shock factor and heat shock response; Cell 65 363-366

Tojo S, Kiguchi K, Kimura S 1981 Hormonal control of storage protein synthesis and uptake by the fat body in the silkworm Bombyx mori; J. Insect. Physiol. 27 491-497

Wyatt G R and Pan M L 1978 Insect Plasma Protein; Annu. Rev. Biochem. 47 779-817

Corresponding editor: M S SHAILA 